\section{Byelorussian intrigue takes new turn}

\section{London}

THE former president of the Byelorussian Academy of Sciences, Mikolah Barysevic, who was replaced last March, exerted "inadequate control" over the institutes of the academy, according to a report in Sotsialisticheskaya Industriya. In particular, the paper said, this lack of control had led to an "abnormal moral and psychological climate" in the academy's Nuclear Power Institute. The director of the institute, V. Niescerau, was relieved of his post in July; a committee of enquiry, however, put much of the blame on the leadership of the academy, and, in particular Barysevic.

What precisely went wrong at the Nuclear Energy Institute is unclear. A handbook on the "scientific potential" of Byelorussia, published earlier this year, speaks well of its work on gas-cooled fastbreeder reactors and applications of gamma-radiation in the production sector. Nor was the replacement of the ageing Barysevic by 48-year-old Uladzimir Platonau viewed, at first, as anything more that the implementation of $\mathrm{Mr}$ Gorbachev's policy of "rejuvenating" all sectors of Soviet life. Barysevic was a physicist of some repute, who in 1980 received a Lenin Prize for his work on lasers, and initial reports had suggested simply that he was going into honourable retirement.

There is, however, one piece of evidence which may suggest that several months before his replacement, Barysevic was aware of criticisms of slackness, and tried to counter them before they became official. In autumn 1986, he made the allegation, expressed in the weekly Literaturnaya Gazeta, that Professor Hollis B. Chen of the University of Ohio had plagiarized the work of the Byelorussian physicist Fiodar Fiodarau. (Since Barysevic's own scientific reputation was assured, any pending criticisms would refer, rather, to his role as leader of the academy - and his defence of Fiodarau could be cited as evidence of his concern for the interests of his academicians.) The controversy dragged on for several months, becoming if anything stronger after a commission of enquiry set up by Ohio University pronounced Chen not guilty of deliberate plagiarism. Then, almost immediately after Barysevic was replaced as president of the Byelorussian Academy of Sciences, the campaign stopped. This may be simply coincidence. But it is noteworthy that Fiodarau, the 'victim' of the alleged plagiarism, who never, incidentally, made any public charges on his own behalf, is now in friendly correspondence with Ohio University, including the members of the commission which cleared Chen. Vera Rich

\title{
First steps towards preserving the Earth's ozone layer
}

Washington

To maintain the international harmony achieved in the signing of the Montreal Protocol to reduce atmospheric ozone depletion, the US Environmental Protection Agency (EPA) has decided to cut back production of chlorofluorocarbons (CFCs) and halons precisely in line with the minimum demands of the protocol, but no further.

CFC production will first be frozen at 1986 levels, then reduced by 20 per cent in 1993 and finally by 50 per cent in 1998 . Halons, which are not yet thought to be significantly active in ozone destruction, will be locked at 1986 production levels after 1992. These reductions are supposed to ensure that global ozone levels remain unchanged and stable in the long term.

The proposed rules have been widely criticized by a number of environmental groups, which claim that EPA, under pressure from business interests and the Reagan administration, is backsliding. Previous EPA studies showed that an 85 per cent cut would be needed simply to keep atmospheric CFC concentrations from increasing.

Although the Montreal agreement specifically allows participating nations to take more stringent action, EPA administrator Lee Thomas says that several countries were not at the outset convinced that any cuts were needed, and he regards it as important to "keep faith" with the compromise. But it is also true that industry has consistently lobbied hard against unilateral action on the grounds that it would damage the United States in the world market.

David Lindley

\section{Britain's synchrotron partners reject 10 per cent solution}

\section{London}

FRANCE and West Germany are blocking Britain's membership of the European Synchrotron Radiation Facility (ESRF), complaining that a subscription fee equivalent to 10 per cent of the project's total cost is too little. At last week's meeting of ESRF's provisional council in Paris, it was made clear that Britain's offer was not acceptable. The governments of the three countries must now reach an agreement before the end of this year.

Disappointed British delegates had lobbied strenuously for a share of the domestic science budget. A few weeks earlier, the Science and Engineering Research Council (SERC) had announced that it could afford no money towards ESRF membership. But a week before the Paris meeting, the Advisory Board for the Research Councils, which advises the government on how the science budget should be distributed, allocated extra money to SERC, sufficient for a 7 per cent subscription to ESRF, with SERC itself finding the remaining 3 per cent.

Although the British contingent was aware that the other member states would be looking to Britain to shoulder nearer 14 per cent of the costs of the 11-year, $£ 350$ million project, it hoped that any objections would be cleared up on the day.

The memorandum of understanding between the member states that permitted a $£ 3$-million foundation study to begin two years ago expires at the end of this year. For the construction phase to start, an international convention is needed, which is likely to take up to six months to com- plete (certain member states require parliamentary approval). In the meantime, an interim intergovernmental protocol has been agreed that will allow work to begin on time, nominally on 1 January next year.

Provisional subscription levels (apart from Britain's) were agreed last week, with France, the host nation for the Grenoble-based venture, agreeing to contribute up to 38 per cent and Germany up to 28 per cent (depending on Britain's eventual contribution; in either case not less than 35 per cent and 25 per cent respectively), Italy 15 per cent, and 4 per cent each (the minimum allowable contribution) from Switzerland, Spain and a Nordic consortium comprising Norway, Sweden, Denmark and Finland.

Despite last week's setback, British synchrotron users remain hopeful that ministers will reach an agreement within the next fortnight that will secure Britain's membership of the consortium. One possible compromise would be to extend the principle of juste retours (where participants in international ventures are awarded staffing and building contracts in proportion to their contributions) to beam-time, with member states allocating their share of the time to their own scientists. Britain's synchrotron community, which would probably stand to lose by such a system, argues that abandonment of the present arrangement, where projects are assessed by their scientific merit by international peer review, would diminish the quality of the science.

Simon Hadlington 